\title{
Vaksinasi Massal Covid-19 sebagai Sebuah Upaya Masyarakat dalam Melaksanakan Kepatuhan Hukum (Obedience Law)
}

\author{
Yusuf Abdul Rahman \\ Pascasarjan UIN Sunan Gunung Djati Bandung, Indonesia \\ Email: 2200010070@student.uinsgd.ac.id
}

\begin{abstract}
After the discovery of a vaccine developed in several countries in, WHO ( World Health Organization) visited all countries to carry out massive vaccinations. Indonesia through Presidential Decree 99/2020 and Minister of Health Regulation 2020 have poured it into a written regulation. However, in this case there are pros (from the legal compliance group) and cons (from the legal compliance group), even though this is a positive step for improvement. In this research, a descriptive research method is used that describes the right of citizens to obey the law (Obedience the law) in vaccinating Covid 19. Then in responding to this policy many community groups reject / disobey the vaccination recommendation that I regret, even though this should be good. by the community and participate in obeying of this recommendation consciously and fairly in order to create an improvement in the situation. Disobedience to the law that the author can do because it is based on the version of the vaccine offered by the current government (sinovac), which has an efficacy value of only $65 \%$ when clinical trials are conducted in Indonesia. However, this should still be achieved as an effort and contribution from the community to participate in breaking the chain that is in Presidential Decree No.99 of 2020 and then it is change in Presidential Decree No.14 of 2021
\end{abstract}

Keywords: Massive vaccination, Obedience law, Covid-19

\begin{abstract}
ABSTRAK
Pasca ditemukannya vaksin yang dikembangkan beberapa negara di dunia, World Health Organization (WHO) merekomendasikan kepada seluruh negara untuk melakukan vaksinasi secara massal. Indonesia melalui Perpres 99 tahun 2020 dan Permenkes 2020 telah menuangkannya menjadi sebuah peraturan tertulis. Namun dalam hal ini terjadi pro (dari kelompok obedience law) dan kontra (kelompok disobedience law), padahal hal ini merupakan sebuah langkah positif demi perbaikan. Dalam penelitian ini menggunakan metode deskriptif yaitu metode yang menggambarkan hak warga negara untuk mematuhi hukum (Obedience law) dalam melakukan vaksinasi covid 19. Kemudian dalam merespon kebijakan ini banyak kelompok masyarakat yang melakukan penolakan/pembangkangan terhadap anjuran vaksinasi yang penulis sayangkan, padahal ini seharusnya disambut baik oleh masyarakat dan ikut mematuhi (obedience law) anjuran ini secara sadar dan fair demi terciptanya sebuah perbaikan keadaan. Pembangkangan terhadap hukum yang dilakukan, disadari karena adanya rasa kekhawatiran atas vaksin yang ditawarkan oleh pemerintah saat ini (sinovac), yang memiliki nilai efikasi hanya $65 \%$ ketika dilakukan uji klinis di indonesia. Namun tetap saja sebaiknya hal ini harus ditempuh sebagai sebuah upaya dan kontribusi dari masyarakat untuk ikut bekerjasama dalam hal memutus mata rantai penyebaran sebagaimana yang tertuang dalam Perpres no 99 tahun 2020 yang kemudian dirubah ke dalam PerPres Nomor 14 Tahun 2021
\end{abstract}

Kata Kunci: Vaksinasi massal, Obedience law, Covid-19

\section{PENDAHULUAN}

Covid 19 yang sudah mewabah sejak Desember 2019 saat ini berdasarkan data dari World Health Organization (WHO) sudah menjangkit di lebih dari 230 negara di dunia, dengan total angka kasus secara

* Copyright (c) 2021 Yusuf Abdul Rahman

This work is licensed under a Creative Commons Attribution-ShareAlike 4.0 International License. 
Khazanah Hukum, Vol. 3 No. 2: 80 - 86

Vaksinasi Massal Covid-19 sebagai Sebuah Upaya Masyarakat dalam Melaksanan Kepatuhan Hukum (Obedience Law)

Yusuf Abdul Rahman

kumulatif pertanggal 5 Februari 2021 sebanyak 116.874 .912 kasus. Di Indonesia sendiri sampai hari ini angka kasus sudah mencapai 1.392 .945 kasus (WHO, 2020), dengan penambahan kasus terbaru sebanyak 6.389 kasus per tanggal 9 Maret 2021 (Mashabi, 2021).

Langkah pemerintah dalam hal ini menurut penulis cukup ekstrim, karena dalam PerPres Nomor 14 Tahun 2021 itu disebutkan adanya pemberian sanksi berupa sanksi administrative sampai pidana bagi setiap orang yang sudah ditetapkan sebagai sasaran penerima vaksin covid-19 yang menolaknya. Jika mengingat kembali, terhadap proses pembuatan vaksin yang notabenenya cepat, dikhawatirkan akan menimbulkan berbagai efek samping dalam jangka panjang (Prastyowati, 2020). Namun penulis pun disisi lain sangat mengharapkan dengan adanya kebijakan ini, mengingat kondisi pertambahan jumlah angka covid 19 yang semakin meningkat setiap harinya, hingga sudah hampir satu bulan terhitung sejak tanggal 8 Januari 2021 pemerintah di Jawa dan Bali sudah melakukan Pemberlakukan Pembatasan Kegiatan Masyarakat (PPKM).

Dalam penelitian Hafidzi (2020) mengenai Kewajiban Penggunaan Vaksin: Antara Legalitas dan Formalitas Perspektif Maqashid Al-Syariah yang sejatinya memang bukan membahas mengenai vaksinasi covid-19 melainkan vaksinasi meningitis kepada para Jemaah haji, akan tetapi apabila dilihat dari segi hukum terutama hukum islam proses pemberian vaksinasi ini merupakan suatu kebolehan dan pada kondisi terkait memang dapat menjadi sebuah kewajiban. Walaupun objek dan kondisinya berbeda, namun dalam penelitian tersebut dapat memberikan informasi tentang vaksinasi. penelitian Masnun et al (2021) mengenai Perlindungan atas Vaksin Covid-19 dan tanggung jawab negara pemenuhan vaksin dalam mewujudkan negara kesejahteraan membahas tentang peran dari negara dalam melakukan pemenuhan vaksin covid-19 yang akan diedarkan. Karena, pada dasarnya vaksin ini akan menjadi sebuah komoditi (menjadi barang dagang) yang memiliki nilai ekonomis. Maka dari itu harus ada instrumen hukum yang mengatur dengan jelas untuk mekanisme ini. Yuningsi (2020) meneliti mengenai Uji Klinik Coronavas dan Rencana Vaksinasi Covid-19 Massal di Indonesia menerangkan bahwa rencana vaksinasi yang akan dilakukan adalah langkah yang efektif dalam menangulangi penularan penyakit. Tujuannya adalah untuk melndungi kesehatan masyarakat dari ancaman covid-19, selain itu juga dalam jangka panjang diproyeksikan untuk dapat mengurangi dampak sosial dan ekonomi yang saat ini sudah timbul akibat pandemik covid-19. Namun, jika ditelusuri dari beberapa penelitian terdahulu terdapat kekosongan kajian mengenari vaksinasi massal (vaksin covid-19) terhadap masyarakat dan penekanan bahwa proses vaksinasi tersebut merupakan sebuah upaya masyarakat dalam melakukan kepatuhan hukum (Obedience law). Tujuan dari penelitian ini secara perlahan diharapkan dapat memberi kesadaran terhadap masyarakat untuk sama-sama melek terhadap isu-isu hukum seputar vaksinasi covid-19 yang akan dilakukan yang saat ini masih terjadi sebuah pro dan kontra.

Apabila merujuk pada peraturan perundang-undangan yang ada, misalnya pada Pasal 14 UndangUndang Nomor 14 Tahun 1984 tentang Wabah Penyakit Menular dan Pasal 9 jo Pasal 93 Undang-Undang Nomor 6 Tahun 2018 tentang Karantina Kesehatan terdapat sanksi pidana bagi masyarakat yang menolaknya. Namun menariknya, di dalam Undang-undang Nomor 36 Tahun 2009 tenang kesehatan (merujuk pada Pasal 5) mengatakan bahwa "Setiap orang berhak secara mandiri dan menentukan sendiri pelayanan kesehatan bagi dirinya", yang secara tidak langsung dapat memberi penjelasan apabila vaksinasi ini bisa menjadi pilihan bagi seseorang dalam melakukan pengobatan (hak pribadi).

Kemudian menjadi menarik menurut penulis mengenai, peraturan tentang Vaksinasi apabila dilihat dari sudut pandang filsafat hukum merupakan sebuah kajian tersendiri. Apalagi terhadap respon yang diberikan oleh masyarakat mengenai pro-kontra yang cukup ramai dibicarakan dan masuk terhadap kajian menurut teori Obedience law dan Disobedience law. Penolakan yang dilakukan oleh masyarakat 
Khazanah Hukum, Vol. 3 No. 2: 80 - 86

Vaksinasi Massal Covid-19 sebagai Sebuah Upaya Masyarakat dalam Melaksanan Kepatuhan Hukum

(Obedience Law)

Yusuf Abdul Rahman

terhadap peraturan pelaksanaan vaksin (Disobedience law) bukan tanpa tujuan, melainkan disebabkan oleh adanya ke-khawatiran terhadap efikasi vaksin yang beredar (sinovac) di Indonesia hanya berkisar $65 \%$ (CNN, 2021). Secara garis besar dalam penelitian ini, saya akan mengungkapkan bahwa vaksinasi massal merupakan sebuah keharusan yang harus dipenuhi dalam masa pandemik, demi menanggulangi permassalahan wabah covid 19 yang melanda seluruh dunia agar cepat ditanggulangi.

\section{METODOLOGI PENELITIAN}

Penelitian ini adalah sebuah penelitian deskriptif yaitu penelitian yang memberikan gambaran mengenai hak warga negara untuk mematuhi hukum (Obedience the law) dalam melakukan vaksinasi covid 19 yang dilakukan secara massal dan menjadi sebuah kebijakan publik. Kemudiaan pendekatan dalam penelitian ini menggunakan pendekatan yuridis normatif yang didukung pendekatan yuridis empiris (Arliman, 2018). Yaitu pendekatan yang dilakukan dengan mengkaji semua data dan bahan yang telah penulis dapatkan dari hasil pencarian dan penelitian terhap sumber-sumber literatur dan fakta empirik yang berkembang secara umum, kemudiaan setelah itu akan disusun dan dianalisis secara kualitatif, dengan tujuan untuk dapa mengetahui dan menyingkap fenomena yang berkembang seputar vaksinasi massal Covid-19 dengan kepatuhan terhadap hukum.

\section{HASIL DAN PEMBAHASAN}

\section{Vaksinisasi}

Sebelum membahas pada materi inti, disini penulis hendak mengulas sedikit mengenai beberapa pengertian mengenai vaksin, guna menjadi sebuah guide dalam memahami tulisan ini secara utuh dan holistik. Secara bahasa vaksin berasal dari bahasa Inggris yaitu vaccine artinya suspensi yang berasal dari bibit penyakit yang hidup tapi sudah dilemahkan (Hafidzi, 2020). Kemudian secara Istilah vaksin merupakan sebuah produk biologis yang terbuat dari kuman, komponen kuman yang telah dilemahkan atau dimatikan yang berguna untuk merangsang timbulnya kekebalan spesifik secara aktif terhadap penyakit tertentu (Kristini, 2008).

Kemudian vaksinasi diistilahkan sebagai sebuah upaya pemberian vaksin kepada spesimen yang dapat merangsang terbentuknya sebuah system imunitas dalam tubuhnya (Martira Maddeppuneng, 2018). Sementara itu vaksinasi massal merupakan pemberian vaksin secara serentak kepada masyarakat untuk menciptakan atau terbentuknya herd imunity.

\section{Pertentangan antara kepatuhan hukum dan penolakan terhadap pelaksanaan vaksinasi}

Dalam teori penolakan/pembangkangan hukum yang dikemukakan oleh Thoreu bahwa sikap penolakan terhadap hukum (Civil Disobedience) merupakan sebuah sikap yang dimiliki oleh masyarakat yang memutuskan untuk tidak mau tunduk terhadap suatu peraturan yang dikeluarkan oleh pemerintah yang berkuasa atau singkatnya menentang sebuah kebijakan publik. Sikap penolakan yang dimiliki oleh masyarakat ini, biasanya didasari oleh sebuah alasan-alasan logis mengenai penolakan atau ketidaksetujuan masyarakat terhadap suatu kebijakan (Thoreau \& MacLeish, 2001). Pada hal ini kaitannya dengan perintah vaksinasi covid 19 yang dilakukan secara massal dengan tujuan menghambat penularannya, melalui penegasan dalam Perpres dan Permenkes.

Akan tetapi ketika melihat fakta yang timbul di lapangan banyak sekali masyarakat yang ramairamai menolak untuk melakukan pemberian vaksin ini, tentunya dengan berbagai alasannya seperti yang 
Khazanah Hukum, Vol. 3 No. 2: 80 - 86

Vaksinasi Massal Covid-19 sebagai Sebuah Upaya Masyarakat dalam Melaksanan Kepatuhan Hukum

(Obedience Law)

Yusuf Abdul Rahman

ditemukan di sosial media mainstream seperti twitter. Penolakan-penolakan tersebut berasal dari keluhan-keluhan masyaakat yang mengkhawatirkan tentang efikasi vaksin yang akan beredar di Indonesia hanya berkisar di angka 65\%.

Kondisi ini diperparah dengan adanya seruan dari salah seorang tokoh anggota parlemen dalam lembaga Dewan Perwakilan Rakyat (DPR) yang menyatakan bahwa lebih baik bayar denda daripada harus di vaksin. Kegaduhan-kegaduhan inilah yang pada akhirnya menyebabkan sebuah kondisi dimana semua orang berada dalam kondisi yang ragu untuk melkasanakan vaksinasi massal. Dalam pendapat Thoreau setidaknya ada tiga kemungkinan yang melatarbelakangi timbulnya sebuah penolakan yang dilakukan oleh masyarakat (Thoreau \& MacLeish, 2001).

Pertama, ada sebuah kelompok masyarakat yang memiliki anggapan dan memiliki pilihan untuk tidak setuju tetapi tetap bungkam, serta mau mengekspresikan pernyataan dan pendapat ketidaksetujuannya, dikarenakan ketakutan akan mendapatkan stigma dan cap sosial di masyarakat terhadap ketidaksetujuannya itu. Kedua, ada sebuah kelompok yang tetap mematuhi hukum kemudian mereka dapat di muka umum, seperti yang kita dengar akhir-akhir ini itulah mereka. Ketiga, kelompok yang menolak untuk mematuhi hukum namun tetap menyembunyikan pendapat ketidaksetujuaannya terhadap vaksinasi massal sehingga tidak diketahui oleh publik secara luas.

Pada dasarnya pertentangan terhadap sebuah kebijakan publik adalah sebuah hal yang tidak dapat dihindari. Kebijakan publik merupakan sebuah produk politik yang dikeluarkan pemerintah dengan maksud dan tujuan untuk mengatur masyarakat supaya berlaku tertib dalam tatanan kehidupan (Widodo, 2021). Akan tetapi, dalam iklim negara demokrasi dikenal juga dengan aspirasi publik yang menitik beratkan agar sebuah sistem yang dijalankan memiliki dimensi hukum yang luwes dan relatif, sehingga tidak terjadi pemakssaan kehendak.

Banyak pihak seperti yang diliput oleh media masa menyanyangkan sikap pemerintah yang memaksakan kehendak untuk mewajibkan penyuntikan vaksin secara massal, padahal setiap orang memiliki kebebasan untuk memilih di tatanan kehidupan yang demokratis. Menurut Jhon Raws civil Disobedience ini memiliki sebuah kewaajiban yang lahir secara natural untuk menegakan sebuah keadilan dalam tatanan masyarakat. Gerakan ini sebetulnya digunakan masyarakat sendiri untuk mencari sebuah keadilan dalam masyarakat (Julaiha, 2020). Ada hal yang seharusnya terjadi terhadap pertentangan antara penolakan dan keharusan mematuhi hukum dalam pelaksanaan vaksinasi massal ini terletak pada objek hukumnya yakni mengoreksi untuk sebuah peraturan yang berlaku.

Secara aturan bila diperhatikan lebih lanjut dalam PerPres nomor 99 Tahun 2020 kemudian diubah dengan PerPres Nomor 14 Tahun 2021 dengan PerMenKes nomor 84 memang secara tegas mengatur tentang tahapan-tahapan pelaksanaan mulai dari perencanaan, pengadaan, sasaran, pelaksanaan sampai pada sanksi bagi yang menolaknya. Sebetulnya hal ini akan berdampak positif bagi masyarakat. Namun secara penegasan sanksi dan denda terhadap orang-orang yang menolak divaksin adalah sesuatu yang menimbulkan keadaan menjadi cukup sensitif. Di tengah kondisi perekonomian yang sedang sulit seperti ini, dimana tingkat kemiskinan meningkat, isu-isu seperti ini akan sangat ditentang dan menyinggung banyak pihak. Karena tidak semua orang mau melakukan vaksinasi secara massal, sebab itu tadi dalam sebuah negara demokrasi disebutkan bahwa setiap orang mempunyai kebebasan untuk menentukan pilihannya. Terkecuali terhadap hal-hal yang dapat menentang pidana, dan hukum positif yang berlaku. Apabila seseorang yang tidak melakukan vaksinasi dianggap sebagai orang yang tidak mematuhi hukum dan dicap sebagai tindakan pidana bisa saja dikenakan sanksi. Tapi dalam hal ini tidak demikian, hukum tetap memiliki koridor dan rambu-rambu dalam penentuan kategorisasi hukum. 
Khazanah Hukum, Vol. 3 No. 2: 80 - 86

Vaksinasi Massal Covid-19 sebagai Sebuah Upaya Masyarakat dalam Melaksanan Kepatuhan Hukum

(Obedience Law)

Yusuf Abdul Rahman

Civil disobedience ini merupakan sebuah gerakan yang bersifat non kekerasan (Gillon, 2003) dengan tujuan untuk melakukan negosiasi dengan pemerintah. Dalam hal ini berarti seorang anggota masyarakat atau kelompok masyarakat harus mengesampingkan sebuah sikap yang dapat merusak dan egoistis, Pembangkangan warga terhadap hukum ini (Disobedience law) sebetulnya dapat dilakukan dengan tindakan secara langsung seperti demonstrasi, pengerahan massa, atau dengan menduduki sebuah tempat tertentu. Semua ini memiliki tujuann untuk memberi sebuah pelajaran kepada publik dan pemerintah agar tidak terjerumus pada sebuah keadaan yang lebih buruk. Namun dalam keadaan covid19 seperti ini hal-hal yang biasa dilakukan tersebut mungkin akan cukup beresiko bila dilakukan, karean tidak sejalan dengan anjuran dari $W H O$ dan pemerintah untuk tidak membuat kerumunan.

\section{Vaksinasi Covid-19 sebagai upaya melakukan Kepatuhan Hukum}

Kepatuhan hukum merupakan sebuah upaya yang dilakukan oleh warga untuk tunduk dan patuh kepada hukum (baik berupa kebiijakan publik, undang-undang atau peraturan lain yang legal) yang dikeluarkan oleh institusi yang memiliki wewenang seperti pemerintah (Usman, 2015). Konsep kepatuhan hukum biasa dalam istilah biasa dikenal dengan Obdience law, konsep ini sangat erat kaitannya dengan moral warga yang ada di sebuah komunitas sosial. Sebab kepatuhan terhadap hukum yang dipilih oleh warga negara merupakan sebuah pilihan yang tersedia, dimana warga berhak untuk menaatinya ataupun tidak menaatinya.

Dalam kasus vaksinasi covid-19 yang dilakukan secara massal ini, tentu ada hal-hal yang perlu diperhatikan untuk memahami terlebih dahulu maksud dan tujuan diberikannya vaksianasi massal. Secara garis besarnya peranan dari peraturan pelaksanaan vaksinasi ini memiliki tujuan untuk memutus rantai penyebaran virus covid-19 yang sudah menjadi wabah secara global semenjak satu tahun terakhir, dan telah menyebabkan banyak kerugian bagi masyarakat.

Akan tetapi, ketika memilih untuk tidak meanaatinya maka warga harus memberikan alasanalasan tertentu sebagaimana yang sudah dijelaskan sebelumnya mengenai Civil Disobdience. Tunick (2019) mengatakan bahwa "hukum tidak boleh dipahami hanya sebagai undang-undang semata yang memang sengaja bisa dibuat atau bisa dicabut sesuai keinginan kita, dan kepatuhan atau tidak patuh bergantung pada kenyamanan kita - terutama bukan hukum pidana". Pada konteks ini berns ingin menyampaikan bahwa posisi undang-undang bukan hanya sebagai aturan yang kehadirannya bukan semata sebagai dibuat untuk kepatuhan warga, melainkan kepada sesuatu moral hukum dan moral masyarakat itu sendiri selama tidak berkaitan dengan hukum pidana.

Kemudian, dalam konteks ini tinggal negara sebagai otoritas tertinggi memberikan sebuah klasifikasi pelanggaran terhadap orang atau masyarakat yang hendak menolak vaksinasi massal dikategorikan sebagai tindakan pidana atau bukan. Bilamana terkategori sebagai tindakan pidana apakaah telah memenuhi unsur pidana seperti actus reus dan mens rea (Herring, 2020) dalam pengkategorisasian unsur-unsur pidana para penolak vaksin covid-19 ini. Menurut saya, sebetulnya hal ini tidak mudah untuk diambil sebagai suatu pelanggaran pidana, tetap ada batasan-batasan yang membedakan antara keharusan dan kewajiban, yakni payung hukum yang digunakan belum menjadi sesuatu yang memiliki supremasi kuat. Tetap dimungkinkan pada sebuah pilihan masyarakat atas sebuah tindakan ini.

Pilihan masyarakat untuk patuh ataupun tidak patuh terhadap vaksinasi ini memiliki sebuah konsekuensi yang logis. Apabila diamati yang beranggapan bahwa melanggar hukum termasuk sesuatu hal yang buruk dan juga kurang etis, juga dapat menimbulkan kekhawatiran di sebagian kalangan karena tidak akan terbentuknya herd immunity secara sempurna. Kemudian ketika dilihat secara moral (bahwa 
Khazanah Hukum, Vol. 3 No. 2: 80 - 86

Vaksinasi Massal Covid-19 sebagai Sebuah Upaya Masyarakat dalam Melaksanan Kepatuhan Hukum

(Obedience Law)

Yusuf Abdul Rahman

hukum itu tidak boleh dipahami hanya sebagai undang-undang semata yang dibuat atau dicabut sesuai keinginan) ini dapat memberikan keleluasan kepada warga negara untuk membuat pilihan yang politis (Achmad Ali \& Wiwie Haryani, 2014).

Namun apabila seseorang hendak mematuhi vaksinasi ini, maka dia harus konsekuen dengan tindakan yang dipilihnya dan memaparkan argumenasinya, mengapa harus mendukung vaksinasi atau mematuhi peraturan ini? Menurut saya ada beberapa alasan argumentasi yang dapat mendorong seseorang untuk mematuhi anjuran vaksinasi ini, diantaranya:

1. Karena faktor keharusan, apabila kepatuhan di dasarkan sebagai sebuah "Keharusan" untuk mematuhi hukum maka ini dapat mengungkapkan bahwa kewajiban institusional tidak selalu memiliki kekuatan moral, karena memang ada paksaan warga negara harus patuh terhadap apa yang disampaikan oleh pemerintah dengan mengikuti keinginan vaksinasi massal covid-19 ini;

2. Karena faktor penularan, faktor ini menyatakan bahwa warga negara mematuhi harus mematuhi vaksinasi ini, karena jika seseorang mulai secara selektif tidak mematuhi anjuran vaksinasi massal ini, ketidakpatuhannya tersebut akan dapat menyebar ke orang lain untuk melakukan tindakan yang serupa. Misalnya jika salah seorang anggota DPR RI kemarin contohnya yang dengan terang-terangan tidak ingin mematuhi anjuran mengenai vaksinasi massal, secara tidak langsung ketika dirinya disorot media dan muncul dalam headline pemberitaan dapat membuat stigma masyarakat untuk mengikuti jejaknya. Kemudian, pada akhirnya di titik paling mengerikannya hal ini dapat memicu sebuah kekacauan dan akan terus meluas, karena akan banyak orang yang menolak vaksinasi ini.

3. Karena faktor keadilan, argumen keadilan disini diartikan sebagai sebuah kepatuhan yang didasari dari kontribusi seseorang dalam melakukan sebuah upaya kepatuhan hukum dengan manfaat yang akan ia dapatkan dari hasil kepatuhan hukum terhadap anjuran vaksinasi ini bisa mengakibatkan ia menjadi kontributor pemutus rantai penularan covid-19 versi pemerintah.

Apabila dicermati kembali kepatuhan terhadap vaksinasi ini memang sangat erat kaitannya dengan sikap moral dan kesadaran masyarakat itu sendiri dalam memahami sebuah situasi dan mengkaji kebijakan hukum yang dilahirkan oleh pemerintah. Rosana (2014) Menurut hemat saya atas dasar ini, memang perlu ditumbuhkan nilai-nilai kesadaran bagi seluruh warga negara agar mau memahami pentingnya vaksinasi massal, demi tumbuhnya herd imunity secara sempurna. Antara kesadaran dan moral memang memiliki kaitan yang inheren dimana dapat dikatakan bila kesadaran memang dapat melahirkan moral yang hidup di masyarakat dan partisipasi masyarakat demi pembangunan negara yang berlandaskan azas hukum meningkat. Karena pada dasarnya, kesadaran itu merupakan core dari lahirnya sebuah moral seseorang dalam mematuhi sebuah peraturan yang ada.

\section{SIMPULAN}

Anjuran terhadap upaya vaksinasi covid 19 yang dilakukan secara massal oleh pemerintah Republik Indonesia merupakan sebuah Langkah positif dalam menekan angka pertumbuhan pandemik covid 19. Melalui perpres No 99 tahun 2020 dan Permenkes 84 tahun 2020 sudah menjadi guide yang bisa dijadikan acuan bagi masyarakat untuk patuh terhadap pelaksanaan vaksinasi secara massal ini, karena memiliki nilai manfaat yang akan membawa masyarakat terbebas dari wabah ini dengan meningkatkan kekebalan tubuh dengan cara herd immunity. Kepatuhan hukum ini atau obedience law, dalam pandangan filsafat hukum ini merupakan pilihan yang dapat diambil masyarakat dalam merespon kebijakan hukum yang lahir. Adanya anjuran vaksinasi ini, merupakan sebuah langkah mitigasi yang saya sepakati untuk dilakukan oleh pemerintah walaupun penolakan(disobedience law) dari kelompok masyarakat akan tetap 
Khazanah Hukum, Vol. 3 No. 2: 80 - 86

Vaksinasi Massal Covid-19 sebagai Sebuah Upaya Masyarakat dalam Melaksanan Kepatuhan Hukum (Obedience Law)

Yusuf Abdul Rahman

ada. Akan tetapi hal ini merupakan dinamika politis yang merupakan hak dan dimiliki setiap warga negara dalam mengutarakan pendapatnya, dengan catatan selama disobedience law ini memiliki landasan yang beralasan dan tidak menyalahi koridor ke ranah perbuatan pidana.

\section{DAFTAR PUSTAKA}

Achmad Ali, S. H., \& Wiwie Haryani, S. H. (2014). Sosiologi hukum: kajian empiris terhadap pengadilan. Kencana.

Arliman, L. (2018). Peranan Metodologi Penelitian Hukum Di Dalam Perkembangan Ilmu Hukum Di Indonesia. Soumatera Law Review, 1(1), 112-132.

CNN. (2021). Ahli Ungkap Keamanan Vaksin Sinovac RI Efikasi 65,3 Persen. Cnnindonesia. cnnindonesia.com/teknologi/20201223082226-199-585488/ahli-ungkap-keamananvaksin-sinovac-ri-efikasi-653-persen

Gillon, S. M. (2003). The American paradox: A history of the United States since 1945. Houghton Mifflin.

Hafidzi, A. (2020). Kewajiban Penggunaan Vaksin: Antara Legalitas dan Formalitas dalam Pandangan Maqashid Al-Syariah. YUDISIA: Jurnal Pemikiran Hukum Dan Hukum Islam, 11(2), 209-218.

Herring, J. (2020). Criminal Law Concentrate: Law Revision and Study Guide. Oxford University Press.

Julaiha, H. (2020). Pertimbangan hakim Pengadilan Agama Bangil Kelas IB dalam peniadaan Mut'ah pada putusan perkara cerai talak Perspektif Teori Keadilan John Rawls. Universitas Islam Negeri Maulana Malik Ibrahim.

Kristini, T. D. (2008). Faktor-faktor risiko kualitas pengelolaan vaksin program imunisasi yang buruk di unit pelayanan swasta (studi kasus di Kota Semarang). Program Pasca Sarjana Universitas Diponegoro.

Mashabi, S. (2021). Update: Tambah 6.389, Jumlah Kasus Covid-19 di Indonesia 1.392.945 Orang. Kompas.Com. https://nasional.kompas.com/read/2021/03/09/17215171/updatetambah-6389-jumlah-kasus-covid-19-di-indonesia-1392945-orang?page=all

Masnun, M. A., Sulistyowati, E., \& Ronaboyd, I. (2021). PELINDUNGAN HUKUM ATAS VAKSIN COVID-19 DAN TANGGUNG JAWAB NEGARA PEMENUHAN VAKSIN DALAM MEWUJUDKAN NEGARA KESEJAHTERAAN. DiH: Jurnal Ilmu Hukum, 17(1), 35-47.

Prastyowati, A. (2020). Mengenal Karakteristik Virus SARS-CoV-2 Penyebab Penyakit COVID-19 Sebagai Dasar Upaya Untuk Pengembangan Obat Antivirus Dan Vaksin. Biotrends, 11(1), 110.

Rosana, E. (2014). Kepatuhan hukum sebagai wujud kesadaran hukum masyarakat. Jurnal Tapis: Jurnal Teropong Aspirasi Politik Islam, 10(1), 61-84.

Thoreau, H. D., \& MacLeish, A. (2001). Civil disobedience. Virginia Tech.

Tunick, M. (2019). Texting, Suicide, and the Law: The Case Against Punishing Michelle Carter. Routledge.

Usman, A. H. (2015). Kesadaran Hukum Masyarakat Dan Pemerintah Sebagai Faktor Tegaknya Negara Hukum Di Indonesia. Jurnal Wawasan Yuridika, 30(1), 26-53.

WHO. (2020). Situation by Country, Territory \& Area Covid-19. Covid19.Who. https://covid19.who.int/table

Widodo, J. (2021). Analisis kebijakan publik: Konsep dan aplikasi analisis proses kebijakan publik. Media Nusa Creative (MNC Publishing).

Yuningsih, R. (2020). UJI KLINIK CORONAVAC DAN RENCANA VAKSINASI COVID-19 MASSAL DI INDONESIA. Info Singkat : Kajian Singkat Terhadap Isu Aktual Dan Strategies, XII(16). 